\title{
Microbiological quality analysis of different types of popular dried food items
}

\author{
*Ahmed, T., Sharmin, A., Paul, A., Dipu, M.R. and Islam, T. \\ Department of Microbiology, Stamford University Bangladesh, 51. Siddeswari Road, Dhaka 1217, \\ Bangladesh
}

\begin{abstract}
Article history:
Received: 26 February 2020

Received in revised form: 7

March 2020

Accepted: 9 March 2020

Available Online: 3 April

2020
\end{abstract}

Keywords:

Contamination,

Pathogenic bacteria,

Production,

Quality

\section{DOI:}

https://doi.org/10.26656/fr.2017.4(4).080

\begin{abstract}
The study was carried out to investigate the microbiological quality of dried foods which are very popular among kids. Moreover, people from all age groups like it, although adults do not take it on a regular basis, the total consumed amount among the adults are not negligible. Chips, biscuits, muesli, salted peanuts all are dried foods, and all of these can undergo microbial contamination due to the remaining water activity, environmental condition, production processing faults, humidity, temperature etc. In the current study, twenty-four samples were analyzed for microbial quality analysis. Six samples from each category of dried food were subjected to study for the presence of mesophilic organisms, coliforms, molds and other specific food pathogens. Of the samples studied, almost all were found to be contaminated with the mesophilic bacteria $\left(10^{4}-10^{7} \mathrm{CFU} / \mathrm{g}\right)$ and fungus $\left(10^{5}-10^{7} \mathrm{CFU} / \mathrm{g}\right)$. Survival of Vibrio spp. was absent and Salmonella spp. was found in only one sample. Escherichia coli, Pseudomonas spp., Staphylococcus spp. and Shigella spp. were found in many of the samples indicating the poor quality of the dried food items. Overall, the present study revealed that potato chips were highly contaminated by bacteria and fungi. Consuming such contaminated chips may cause foodborne illness that is a great threat to our health.
\end{abstract}

\section{Introduction}

Dried foods like chips, biscuits, muesli or roasted nuts are very popular snack items all over the world which are available in every grocery shop, super shops as well as in the remote areas. These are enjoyed most during vacation, journey, picnic and even as school tiffin. The principal of production of potato chips are cooked and salted potatoes pieces mixed with different kinds of flavorings and ingredients including herbs, spices, cheeses, natural or artificial flavors and additives. A survey results published (Berry and Norman, 2014) that the world potato chip market collected total revenues of US\$16.49 billion in 2005 that was $35.5 \%$ of the total market of snacks in that year ( $\$ 46.1$ billion) (Savory Snacks: Global Industry Guide, 2016). Nuts are a source of protein, fat and minerals. People who are more considerate about their health prefer nuts that junk snacks (Bhat and Vasanthi, 2003). Dried cereals are best suited for a modern busy life as they can be eaten directly with milk without further processing. Cereals are produced by mixing different cereal grains and processing them together (like roasting, grinding, swelling, shredding, flaking and so on). They are a good source of vitamins, minerals, zinc, phosphorus and calcium (Williams, 2014; Mbaeyi-Nwaoha et al., 2016). Another popular dry food is biscuit which mostly contains carbohydrate, and some protein, gluten and fat content (Shewry et al., 2002; Adobowale et al., 2012).

Potato Chips are not only tasty and easily available snack, but also inexpensive. The major fact is the impact of chips on our body is not sound. Due to high oil contents, it is harmful to the peoples suffering from chronic heart diseases and obesity (Consensus Action on Salt and Health, 2004; Prajapati et al., 2003).

There are international standards for the microbiological limit of foods and beverages. These standards can be modified slightly by locally. Almost every country has its own regulations and monitoring body to check the quality of the food, exclusively the ready to eat foods due to its high alarm for human health hazard. As a ready to eat foods, chips, biscuits, salted nuts and muesli have a risk for microbial contamination on its production, packaging, transportation or storage (Fraizer and Westhoff, 1995; Eze et al., 2011; Oladipo et al., 2019). Escherichia coli O157: H7, Salmonella spp., 
Shigella spp., Bacillus spp., Mycobacterium spp., Brucella spp., Listeria monocytogenes, Yersinia enterocolitis, Pseudomonas spp.; Clostridium perfringens, Klebsiella spp., Vibrio spp., Campylobacter jejuni and Staphylococcus aureus have been reported to be the common food spoilage bacteria (Fraizer and Westhoff, 1995; Beuchat et al., 1996; Torquato et al., 2004; Jay et al., 2005; Nordmann et al., 2009; Rahman and Noor, 2012; Acharjee et al., 2013; Hassan et al., 2013; Noor et al., 2014; Oladipo et al., 2019). Furthermore, it contains toxic and carcinogenic byproducts which are not found in the uncooked foods (Exon, 2006).

Potato Chips contaminated by microorganisms (bacteria, yeasts, viruses, and protozoa) can cause healthrelated issues (Jaykus, 2000; Drury, 2012). Contaminated nuts with fungus and associated toxin can cause liver damage, cancer, abortion etc. (Abbas et al., 2005; Drury, 2012).

The objective of the current study was to identify the existence and amount of bacteria (Escherichia coli, Klebsiella spp., Pseudomonas spp., Staphylococcus spp., Shigella spp., Salmonella spp., Aeromonas spp., Vibrio spp.) and fungi in different types of dried foods (potato chips, muesli, biscuits, salted peanuts) to determine their overall quality for assessing the public health risks.

\section{Materials and methods}

\subsection{Study area, sampling}

A total of twenty-four samples of chips, biscuits, muesli and salted peanut (six sample per category of food) with valid manufacturing and expiry dates were collected from April 2017 to May 2017. These samples were collected from different retailer store in Dhaka city, Bangladesh and then transported to the laboratory to determine the microbiological quality of the respective chips.

\subsection{Sample processing}

For each dried food samples, $10 \mathrm{~g}$ were weighed and homogenized with $90 \mathrm{~mL}$ normal saline and serial dilutions were prepared up to $10^{-4}$ and the dilution was used for plating purpose according to the standard protocols (Cappuccino and Natalie, 1983; Cappuccino and Sherman, 1996).

\subsubsection{Enumeration of total viable count (TVC) and total fungal count (TFC)}

For the quantification of total viable count (TVC) and total fungal count (TFC), $0.1 \mathrm{~mL}$ of the $10^{-3}$ and $10^{-4}$ dilutions were spread onto the Nutrient agar (NA) and Sabouraud's dextrose agar (SDA) (Oxoid Ltd.,
Basingstoke, Hampshire, England) plates, respectively, by means of spread plate technique. Plates were incubated at $37^{\circ} \mathrm{C}$ for $24 \mathrm{hrs}$ and $25^{\circ} \mathrm{C}$ for $48 \mathrm{hrs}$ for total viable bacteria and fungi, respectively (Atlas et al., 1995; Cappuccino and Sherman, 1996; Downes and Ito, 2001; Deak, 2003).

\subsubsection{Enrichment of samples}

An aliquot $(1 \mathrm{~mL})$ of the homogenized sample was transferred into $9 \mathrm{~mL}$ of selenite cysteine broth (SCB) and alkaline peptone water (APW) (Oxoid Ltd., Basingstoke, Hampshire, England) for the enrichment of Salmonella, Shigella, and Vibrio spp., Aeromonas spp. respectively and incubated at $37^{\circ} \mathrm{C}$ for $4-6$ hours . Samples were then diluted up to $10^{-3}$ and $0.1 \mathrm{~mL}$ of samples from each of the $10^{-2}$ and $10^{-3}$ dilutions were spread onto Salmonella-Shigella (SS) agar and thiosulfate citrate bile salt sucrose (TCBS) agar (Oxoid Ltd., Basingstoke, Hampshire, England) for the isolation of Salmonella spp., Shigella spp., and Vibrio spp., Aeromonas spp. respectively. Plates were incubated at $37^{\circ} \mathrm{C}$ and the appearance of typical colonies (if any) was noticed within for 24-48 hrs (Samia et al., 2014).

\subsubsection{Isolation and enumeration of Staphylococcus spp. and Pseudomonas spp.}

From the $10^{-3}$ and $10^{-4}$ dilution of each suspension, $0.1 \mathrm{~mL}$ of sample was spread onto Mannitol salt agar (MSA) and Pseudomonas agar (PA) media for the enumeration of Staphylococcus spp. and Pseudomonas spp. consecutively. All the plates were incubated at $37^{\circ} \mathrm{C}$ for 24 hrs (Samia et al., 2014).

\subsubsection{Isolation and enumeration of Escherichia coli, Klebsiella spp.}

From the $10^{-3}$ and $10^{-4}$ dilutions of each suspension, $0.1 \mathrm{~mL}$ of sample was spread onto MacConkey agar media for the enumeration of E. coli and Klebsiella spp. All the plates were incubated at $37^{\circ} \mathrm{C}$ for $24 \mathrm{hrs}$ (Samia et al., 2014).

\section{Results}

\subsection{Microbiological analysis of chips}

From Table 1, we can see that Total viable count (TVC) higher than Total fungal count (TFC) for sample $\mathrm{C} 1, \mathrm{C} 2, \mathrm{C} 5, \mathrm{C} 6$ and in the case of sample $\mathrm{C} 3, \mathrm{C} 4 \mathrm{TFC}$ are higher than TVC. The highest count of TVC $\left(2.8 \times 10^{7}\right.$ $\mathrm{CFU} / \mathrm{g})$ and TFC $\left(1.1 \times 10^{6} \mathrm{CFU} / \mathrm{g}\right)$ was found in sample $\mathrm{C} 2$ and the lowest count of TVC $\left(3.0 \times 10^{5} \mathrm{CFU} / \mathrm{g}\right)$ and TFC $\left(6.0 \times 10^{4} \mathrm{CFU} / \mathrm{g}\right)$ was found in sample $\mathrm{C} 1$. In our study, we also tried to detect the existence of some specific bacteria in potato chips. We found Salmonella spp. $\left(7 \times 10^{4} \mathrm{CFU} / \mathrm{g}\right)$ only in sample C3. Pseudomonas 
spp. (ranging from $2.5 \times 10^{4} \mathrm{CFU} / \mathrm{g}$ to $2.8 \times 10^{5} \mathrm{CFU} / \mathrm{g}$ ), Staphylococcus spp. (ranging from $4 \times 10^{4}$ to $5.2 \times 10^{5} \mathrm{CFU} / \mathrm{g}$ ), Shigella spp. (ranging from $1.0 \times 10^{4}$ $\mathrm{CFU} / \mathrm{g}$ to $7 \times 10^{5} \mathrm{CFU} / \mathrm{g}$ ) was found in all the samples which means that all the samples were produced in such a condition which made the quality unsatisfactory for consumption. E. coli was found only in 3 samples (sample C1, C3, C4).

\subsection{Microbiological analysis of biscuits}

Table 2 shows the overall microbiological quality of biscuits. The highest total bacterial count and total fungal count was found in sample B5. Salmonella spp. and Vibrio spp. were absent. Aeromonas spp. $\left(1.0 \times 10^{3} \mathrm{CFU} /\right.$ g) was found only in sample B5. E. coli, Klebsiella spp. and Shigella spp. was found in 2 samples each. Staphylococcus spp. (ranging from $4.0 \times 10^{3} \mathrm{CFU} / \mathrm{g}$ to $2.6 \times 10^{4} \mathrm{CFU} / \mathrm{g}$ ) and Pseudomonas spp. (ranging from $2.5 \times 10^{4} \mathrm{CFU} / \mathrm{g}$ to $1.4 \times 10^{5} \mathrm{CFU} / \mathrm{g}$ ) were found in all samples.

\subsection{Microbiological analysis of muesli}

From Table 3 (muesli) we can observe that TVC was higher than TFC for all samples. The highest count of TVC $\left(2.7 \times 10^{6} \mathrm{CFU} / \mathrm{g}\right)$ and TFC $\left(1.1 \times 10^{6} \mathrm{CFU} / \mathrm{g}\right)$ was found in sample $\mathrm{M} 2$ and the lowest count of TVC $\left(3.0 \times 10^{5} \mathrm{CFU} / \mathrm{g}\right)$ and TFC $\left(1.9 \times 10^{5} \mathrm{CFU} / \mathrm{g}\right)$ was found in sample M6. Salmonella spp. and Vibrio spp. were totally absent. Pseudomonas spp. (ranging from $1.7 \times 10^{3} \mathrm{CFU} / \mathrm{g}$ to $2.5 \times 10^{5} \mathrm{CFU} / \mathrm{g}$ ), Staphylococcus spp. (ranging from $2.0 \times 10^{4}$ to $2.9 \times 10^{5} \mathrm{CFU} / \mathrm{g}$ ), Shigella spp. (ranging from $1.0 \times 10^{3} \mathrm{CFU} / \mathrm{g}$ to $2.4 \times 10^{4} \mathrm{CFU} / \mathrm{g}$ ) were also was found in all the samples. Klebsiella spp. was present only in sample M4 whereas E. coli was found in sample M3 and sample M6.

\subsection{Microbiological analysis of salted peanut}

Table 4 (salted peanut) depicts the highest count of TVC $\left(2.2 \times 10^{6} \mathrm{CFU} / \mathrm{g}\right)$ in sample P3 and TFC $\left(1.1 \times 10^{6}\right.$ $\mathrm{CFU} / \mathrm{g})$ in sample P2. The lowest count of TVC $\left(2.0 \times 10^{5}\right.$ $\mathrm{CFU} / \mathrm{g})$ was found in sample $\mathrm{P} 2$ and TFC $\left(6.0 \times 10^{5} \mathrm{CFU} /\right.$ g) was found in sample P1. Salmonella spp. and Vibrio spp. was absent like all other dry foods under this study. Aeromonas spp. was found only in sample P2 and P6. E. coli, Klebsiella spp. and Shigella spp. was found to be present in 50\% samples ( 3 out of 6). The highest number of Staphylococcus spp. and Pseudomonas spp. was found in sample P1.

\section{Discussion}

All the samples have a noticeable amount of TFC and TVC that lies on the unsatisfactory levels. According to East African Standard 747, 2010, if the count for chips (per gram) for TVC is $>10^{4}$ and TFC is $>10^{3}$ then it is unacceptable. The presence of Staphylococcus spp., Shigella spp., and Vibrio spp. is not satisfactory to be present as they are potent food spoilers and can cause disease in human upon consumption. Their presence must be controlled to keep consumers safe. Salmonella spp. and E. coli must also be absent in chips (Harris et al., 2002; East African Standard 747, 2010).

If any bacteria from the fecal group (in our study $E$. coli, Klebsiella spp.) is present it means that the quality of the food is not safe to eat. The presence of any amount of fecal bacterium is not acceptable according to the safety guideline of ready dried foods.

In this study, most of the samples showed the presence of E. coli and Klebsiella spp. Other pathogenic bacteria (Pseudomonas spp. and Salmonella spp.) were present in a lower amount (Guan and Holley, 2003).

The presence of such bacteria in dried food items can come during the production process and also after storage if the packaging material is not intact or the storage condition is not good for storing food items. During the production process, many steps are carried out and in many of these steps, there are possible chances of contamination to occur (Figure 1). Mechanical areas in processing line like hopper with feeder, grader, peeler, feed conveyor, slicer, flavor applicator etc. are the areas where attention should be maximized to prevent such unwanted contamination.

Biscuits can be spoiled by different ways like physical, chemical and microbial spoilage. Microbial spoilage often depends on some factors like storage temperature, humidity, storage hygiene, packaging material, the moisture content in the storage area etc. (Ooaraikul, 1991). Peanuts often get contaminated with aflatoxin while storing in conditions with high atmospheric temperature, high humidity, low light and long-term storage (Ostadrahimi et al., 2014).

Dried foods are quite popular fast food item around the world and often we ignore the quality as it is a dry food item. But there are possibilities to become contaminated during production and processing of these foods. Several food poisoning bacteria and fungi can be present if proper good manufacturing practice is not maintained and the people (especially children and other young adults among who such food items are very much popular) consuming such contaminated chips can face serious health issues. Attention should be kept on dry food items like chips to process in such a way to prevent any contamination. 
Table 1. Microbiological analysis of chips (CFU/g)

\begin{tabular}{|c|c|c|c|c|c|c|c|c|c|}
\hline 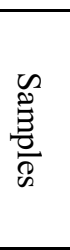 & 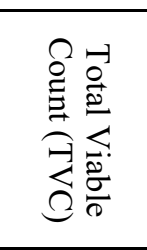 & 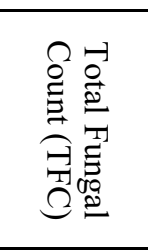 & 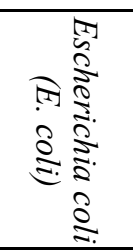 & $\begin{array}{l}\pi \\
\frac{\pi}{2} \\
\frac{0}{0} \\
\frac{0}{2} \\
\frac{0}{0} \\
\frac{0}{0}\end{array}$ & 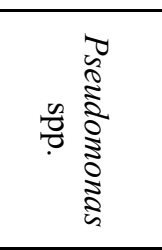 & 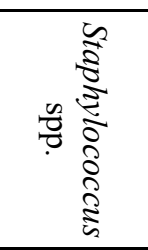 & 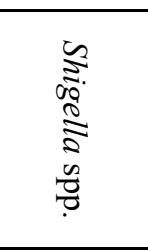 & 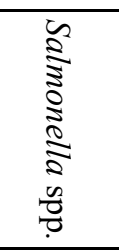 & $\begin{array}{l}\frac{1}{0} \\
0 \\
0 \\
0 \\
0 \\
0 \\
0 \\
0 \\
0\end{array}$ \\
\hline $\mathrm{C} 1$ & $3.0 \times 10^{5}$ & $6.0 \times 10^{4}$ & $4 \times 10^{4}$ & $7.0 \times 10^{4}$ & $1.2 \times 10^{5}$ & $1.4 \times 10^{5}$ & $2.5 \times 10^{5}$ & 0 & $8.0 \times 10^{4}$ \\
\hline $\mathrm{C} 2$ & $2.8 \times 10^{7}$ & $1.1 \times 10^{6}$ & 0 & 0 & $2.8 \times 10^{5}$ & $4.5 \times 10^{5}$ & $1.9 \times 10^{5}$ & 0 & $4.7 \times 10^{4}$ \\
\hline $\mathrm{C} 3$ & $1.3 \times 10^{5}$ & $2.6 \times 10^{5}$ & $2 \times 10^{4}$ & $1.0 \times 10^{4}$ & $8.8 \times 10^{4}$ & $4 \times 10^{4}$ & $1.1 \times 10^{5}$ & $7 \times 10^{4}$ & 0 \\
\hline $\mathrm{C} 4$ & $2.1 \times 10^{6}$ & $1.4 \times 10^{5}$ & $1.5 \times 10^{5}$ & $4 \times 10^{4}$ & $7.5 \times 10^{4}$ & $1.7 \times 10^{5}$ & $1.4 \times 10^{5}$ & 0 & $1.8 \times 10^{5}$ \\
\hline $\mathrm{C} 5$ & $2.8 \times 10^{6}$ & $7.5 \times 10^{4}$ & 0 & $4.6 \times 10^{5}$ & $2.5 \times 10^{4}$ & $4.8 \times 10^{5}$ & $7.0 \times 10^{5}$ & 0 & 0 \\
\hline C6 & $2.2 \times 10^{6}$ & $1.7 \times 10^{5}$ & 0 & $1.3 \times 10^{5}$ & $1.4 \times 10^{5}$ & $5.2 \times 10^{5}$ & $1.0 \times 10^{4}$ & 0 & $1.0 \times 10^{4}$ \\
\hline
\end{tabular}

Table 2. Microbiological analysis of biscuits (CFU/g)

\begin{tabular}{|c|c|c|c|c|c|c|c|c|c|}
\hline 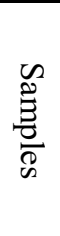 & 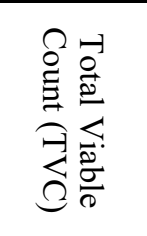 & 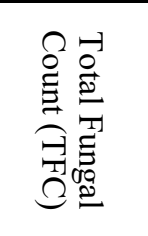 & 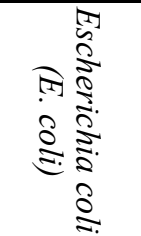 & $\begin{array}{l}\underset{8}{0} \\
0 \\
\vdots \\
0 \\
\frac{2}{2} \\
\frac{0}{0} \\
\frac{0}{0}\end{array}$ & 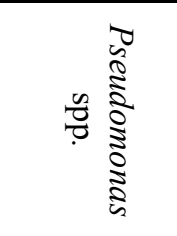 & 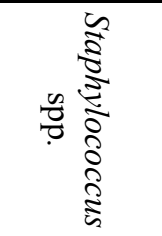 & 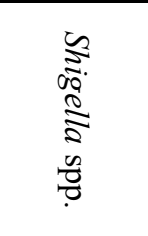 & 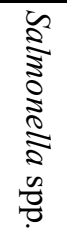 & 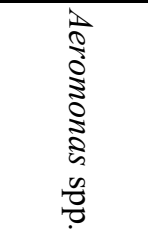 \\
\hline B1 & $2.2 \times 10^{5}$ & $2.0 \times 10^{4}$ & $4 \times 10^{4}$ & 0 & $2.8 \times 10^{4}$ & $2.0 \times 10^{4}$ & 0 & 0 & 0 \\
\hline B2 & $2.0 \times 10^{4}$ & $1.6 \times 10^{5}$ & 0 & 0 & $1.2 \times 10^{5}$ & $1.8 \times 10^{4}$ & 0 & 0 & 0 \\
\hline B3 & $1.0 \times 10^{5}$ & $1.4 \times 10^{4}$ & 0 & $1 \times 10^{4}$ & $1.4 \times 10^{5}$ & $4.0 \times 10^{3}$ & $1.0 \times 10^{3}$ & 0 & 0 \\
\hline B4 & $2.6 \times 10^{4}$ & $2.4 \times 10^{5}$ & $1.5 \times 10^{5}$ & 0 & $8.8 \times 10^{4}$ & $1.7 \times 10^{4}$ & 0 & 0 & 0 \\
\hline B5 & $2.1 \times 10^{6}$ & $2.7 \times 10^{5}$ & 0 & 0 & $2.5 \times 10^{4}$ & $2.6 \times 10^{4}$ & 0 & 0 & $1.0 \times 10^{3}$ \\
\hline B6 & $2.1 \times 10^{5}$ & $1.0 \times 10^{2}$ & 0 & $1.3 \times 10^{3}$ & $7.5 \times 10^{4}$ & $2.2 \times 10^{4}$ & $1.1 \times 10^{3}$ & 0 & 0 \\
\hline
\end{tabular}

Table 3. Microbiological analysis of muesli (CFU/g)

\begin{tabular}{|c|c|c|c|c|c|c|c|c|c|}
\hline $\begin{array}{l}\frac{\tilde{N}}{\tilde{E}} \\
\frac{\tilde{\sigma}}{\infty} \\
\frac{\infty}{\infty}\end{array}$ & 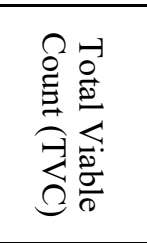 & 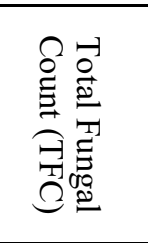 & 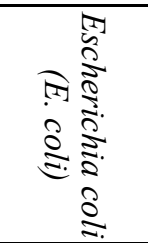 & 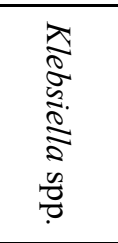 & 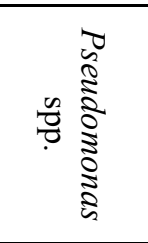 & 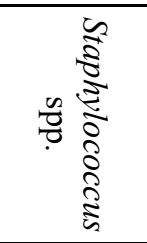 & 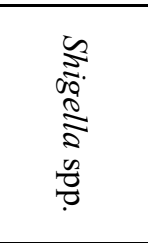 & 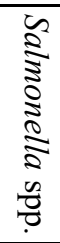 & 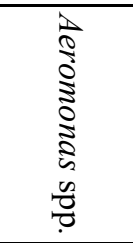 \\
\hline M1 & $1.9 \times 10^{5}$ & $2.9 \times 10^{4}$ & 0 & 0 & $1.0 \times 10^{4}$ & $2.4 \times 10^{5}$ & $2.0 \times 10^{3}$ & 0 & 0 \\
\hline M2 & $1.6 \times 10^{6}$ & $1.1 \times 10^{4}$ & 0 & 0 & $1.8 \times 10^{3}$ & $2.8 \times 10^{4}$ & $1.3 \times 10^{4}$ & 0 & 0 \\
\hline M3 & $2.2 \times 10^{5}$ & $1.6 \times 10^{5}$ & $1.0 \times 10^{3}$ & 0 & $1.0 \times 10^{4}$ & $2.0 \times 10^{4}$ & $2.1 \times 10^{3}$ & 0 & $2.7 \times 10^{3}$ \\
\hline M4 & $2.8 \times 10^{5}$ & $2.1 \times 10^{4}$ & 0 & $4 \times 10^{4}$ & $2.5 \times 10^{5}$ & $2.4 \times 10^{5}$ & $2.4 \times 10^{4}$ & 0 & 0 \\
\hline M5 & $2.8 \times 10^{5}$ & $2.0 \times 10^{5}$ & 0 & 0 & $2.1 \times 10^{4}$ & $2.9 \times 10^{5}$ & $1.0 \times 10^{3}$ & 0 & $1.5 \times 10^{4}$ \\
\hline M6 & $2.7 \times 10^{6}$ & $1.9 \times 10^{5}$ & $1.5 \times 10^{5}$ & 0 & $1.7 \times 10^{3}$ & $2.2 \times 10^{4}$ & $1.6 \times 10^{4}$ & 0 & $1.2 \times 10^{3}$ \\
\hline
\end{tabular}

Table 4. Microbiological analysis of salted peanut (CFU/g)

\begin{tabular}{|c|c|c|c|c|c|c|c|c|c|}
\hline 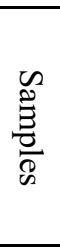 & 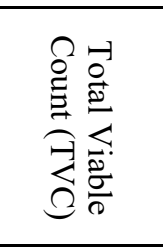 & 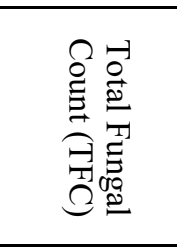 & 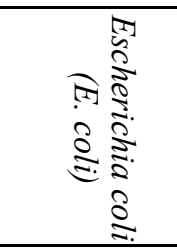 & $\begin{array}{l}\pi \\
0 \\
0 \\
0 \\
0 \\
\vdots \\
0 \\
0 \\
0 \\
0\end{array}$ & 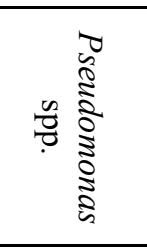 & 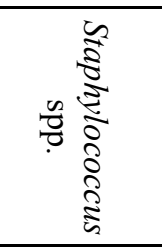 & 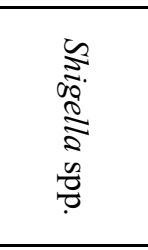 & 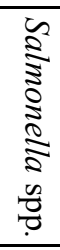 & 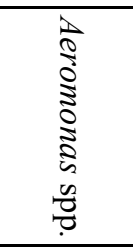 \\
\hline P1 & $1.6 \times 10^{6}$ & $6.0 \times 10^{5}$ & 0 & $5.2 \times 10^{3}$ & $1.0 \times 10^{5}$ & $2.4 \times 10^{5}$ & $1.5 \times 10^{4}$ & 0 & 0 \\
\hline $\mathrm{P} 2$ & $2.0 \times 10^{5}$ & $1.1 \times 10^{7}$ & $4.4 \times 10^{3}$ & $1.0 \times 10^{4}$ & 0 & $1.1 \times 10^{5}$ & 0 & 0 & $1.1 \times 10^{3}$ \\
\hline $\mathrm{P} 3$ & $2.1 \times 10^{6}$ & $2.6 \times 10^{5}$ & $1.2 \times 10^{3}$ & 0 & $8.8 \times 10^{3}$ & $1.5 \times 10^{4}$ & $1.1 \times 10^{4}$ & 0 & 0 \\
\hline $\mathrm{P} 4$ & $2.2 \times 10^{5}$ & $1.4 \times 10^{6}$ & $2.5 \times 10^{4}$ & $2.8 \times 10^{4}$ & $7.5 \times 10^{3}$ & $1.0 \times 10^{5}$ & 0 & 0 & 0 \\
\hline P5 & $2.1 \times 10^{5}$ & $7.5 \times 10^{5}$ & 0 & 0 & $2.5 \times 10^{4}$ & $4.8 \times 10^{3}$ & $1.2 \times 10^{3}$ & 0 & 0 \\
\hline P6 & $2.2 \times 10^{6}$ & $1.7 \times 10^{6}$ & 0 & 0 & $1.4 \times 10^{4}$ & $5.2 \times 10^{3}$ & 0 & 0 & $1.4 \times 10^{3}$ \\
\hline
\end{tabular}




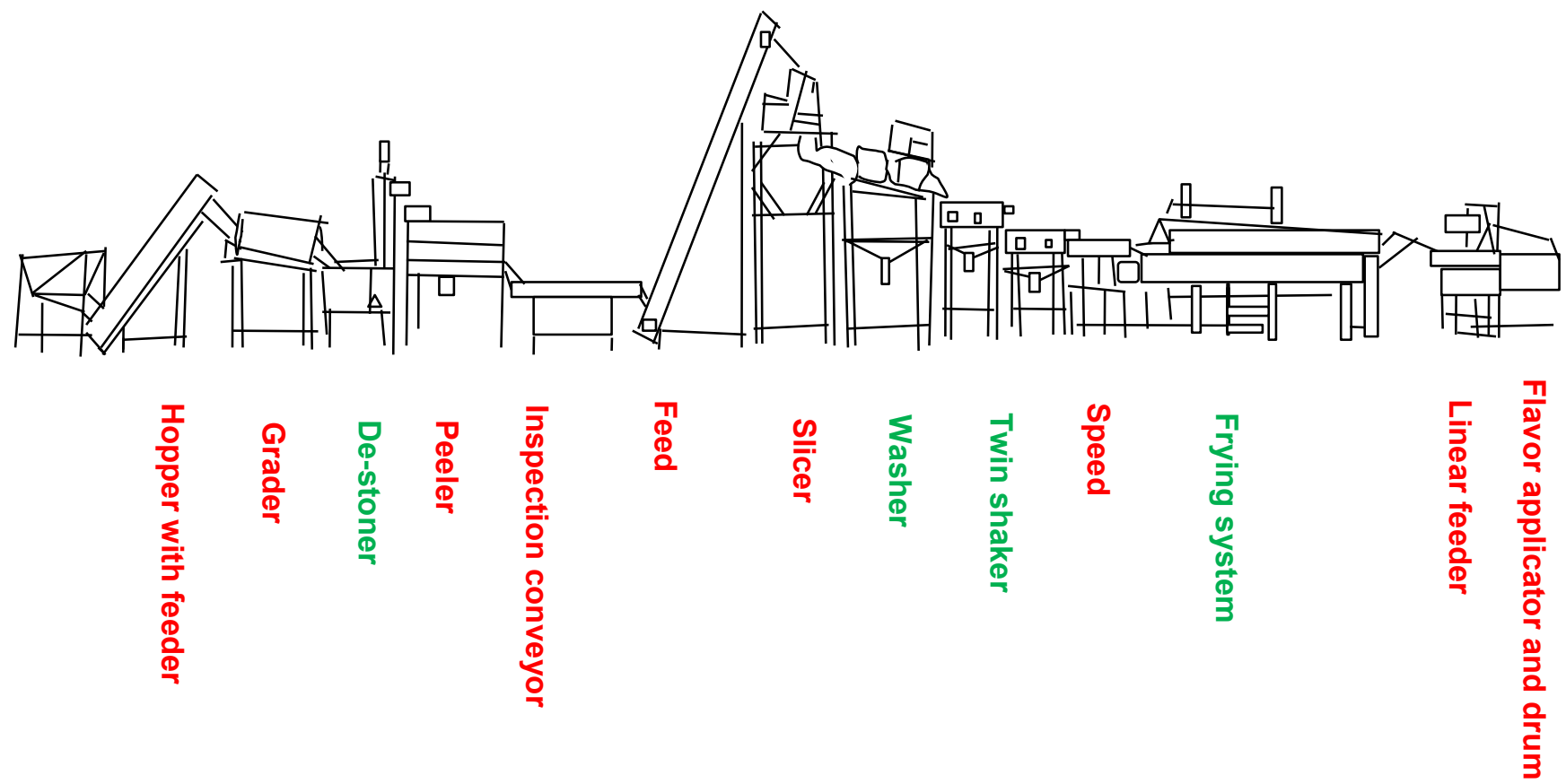

Figure 1. Chips production line. (Green parts are safe and red parts are the areas where contamination can occur)

\section{Conclusion}

Foodborne illness can result in death of people from all age range with a higher ratio for children. Our result indicated that dried foods are contaminated by bacteria and fungi. If people consume such contaminated these contaminated foods, they will suffer from various foodborne diseases. Therefore, routine microbiological analysis of different dried foods is necessary to protect public health. The Government should also take necessary steps to monitor the food quality on a regular basis and enforce the law against those who will fail to produce safety foods.

\section{Conflict of Interest}

The authors have no potential conflict of interest.

\section{Acknowledgement}

Authors would like to thank Stamford University Bangladesh for the financial and technical supports.

\section{References}

Abbas, R., Baldwin, D., Ma, Y., Ouyang, W., Gurney, A., Martin, F., Fong, S., Campagne, M.V.L., Godowski, P., Williams, P.M., Chan, A.C. and Clark, H.F. (2005). Immune response in silico (IRIS): Immune-specific genes identified from a compendium of microarray expression data. Genes and Immunity, 6(4), 319-331. https:// doi.org/10.1038/sj.gene.6364173

Adobowale, A., Adegunwa, M.O., Sanni, S.A. and Ganiyat, O. (2012). Functional Properties and Biscuit Making Potentials of Sorghum-wheat Flour
Composite. American Journal of Food Technology, 7(6), 372-379. https://doi.org/10.3923/ ajft.2012.372.379

Atlas, R.M. (1995). Handbook of microbiological media for the examination of food., p. 310. Boca Raton: CRC Press.

Berry, S. and Norman P. (2014). Crisps buoyed Britain in its darkest hour. Retrieved on August 26, 2014 from The Telegraph Website: https:// www.telegraph.co.uk/foodanddrink/10965628/Crisps -buoyed-Britain-in-its-darkest-hour.html

Beuchat, L.R. (1996). Pathogenic microorganisms associated with fresh produce. Journal of Food Protection, 59(2), 204-216. https:// doi.org/10.4315/0362-028X-59.2.204

Bhat, R.V. and Vasanthi, S. (2003). Food safety in food security and food trade. Mycotoxin Food Safety Risk in Developing Countries. Washington, D.C. USA: International Food Policy Research Institute.

Cappuccino, G. and Natalie, S. (1983). Microbiological Laboratory Manual. $4^{\text {th }}$ ed., p. 180, 295-303. Longman, New York, USA: Addison-Wesley

Cappuccino, J.G. and Sherman, N. (1996). A laboratory manual: standard qualitative analysis of water. 4th ed., p. 299. Boston: Addison-Wesely Longman.

Deak, T. (2003). Food Quality and Standards, Vol. III Testing Methods in Food Microbiology. Hungary: Encyclopedia of Life Support Systems (EOLSS).

Downes, F.P. and Ito, K. (2001). Compendium of methods for the microbiological examination of foods. 4th ed. Washington, D.C. USA: APHA. https://doi.org/10.2105/9780875531755

Drury, R. (2012). Bacterial and Fungal Diseases in Pet 
Birds. International Journal of Systematic Bacteriology, 42(3), 390-10.

East African Standard 747 (2010). Fried Potato chipsspecification. $1^{\text {st }}$ ed. Tanzania: East African Community.

Exon, J. (2006). A review of the toxicology of the acrylamide. Journal of Toxicology and Environmental Health, Part B, 9(5), 397-412. https://doi.org/10.1080/10937400600681430

Eze, E.I., Echezona, B.C. and Uzodinma, E.C. (2011). Isolation and identification of pathogenic bacteria associated with frozen mackerel fish (Scomber scombrus) in a humid tropical environment. African Journal of Agricultural Research, 6(7), 1918-1922.

Fraizer, W.C. and Westhoff, D.C. (1995). Food Microbiology, $4^{\text {th }}$ ed., p. 384-396. New Delhi: Tata McGraw-Hill Publishing Company Limited.

Guan, T.Y. and Holley, R.A. (2003). Pathogen Survival in Swine Manure Environments and Transmission of Human Enteric Illness - A Review. Journal of Environmental Quality, 32(2), 383-392. https:// doi.org/10.2134/jeq2003.3830

Harris, L.G., Foster, S.J. and Richards, R.G. (2002). S. aureus adhesions. European Cells and Materials, 4, 1473-2262. https://doi.org/10.22203/eCM.v004a04

Jay, J.M. (2000). Modern food microbiology, $6^{\text {th }}$ ed. Gaithersburg, Maryland, USA: Aspen Publishers, Inc. https://doi.org/10.1007/978-1-4615-4427-2

Jaykus, L.A. (2000). Detection of human enteric viruses in foods. In Sattar, S. (Ed.) Foodborne disease handbook: viruses, parasites, pathogens, and HACCP. Vol. 2., p. 137-163.

Mbaeyi-Nwaoha, I.E. and Uchendu, N.O. (2016). Production and evaluation of breakfast cereals from blends of acha and fermented soybean paste (okara). Journal of Food Science and Technology, 53(1), 5070. https://doi.org/10.1007/s13197-015-2032-8

Nordmann, P., Cuzon, G. and Naas, T. (2009). The Real Threat of Klebsiella pneumoniae CarbapenemaseProducing Bacteria. Lancet Infectious Diseases, 9(4), 228-36. https://doi.org/10.1016/S1473-3099(09) 70054-4

Oladipo, I.C., Ogunsona, S.B., Ojekanmi, O.S. and Adegoroye, A.O. (2019). Microbial and nutritional evaluation of biscuits produced from wheat and quality protein maize flour. World Journal of Pharmaceutical and Life Sciences, 5(1),5-11.

Ostadrahimi, A., Ashrafnejad, F., Kazemi, A., Sargheini, N., Mahdavi, R., Farshchian, M. and Mahluji, S. (2014). Aflatoxin in raw and salt-roasted nuts (pistachios, peanuts and walnuts) sold in markets of Tabriz, Iran. Jundishapur Journal of Microbiology, 7
(1), e8674. https://doi.org/10.5812/jjm.8674

Prajapati, J.B., Nair, B.M. and Farnworth, E.R. (2003). The history of fermented foods in Fermented Functional Foods., p. 1-25. Boca Raton, USA: CRC Press. https://doi.org/10.1201/9780203009727.ch1

Rahman, F. and Noor, R. (2012). Prevalence of pathogenic bacteria in common salad vegetables of Dhaka metropolis. Bangladesh Journal of Botany, 41 (2), $\quad 159-162 . \quad$ https://doi.org/10.3329/ bjb.v41i2.13442

Samia, S., Galib. H.T., Tanvir, A.S., Basudeb, C.S., Md. Walliullah, Tasnia, A., Md. Sakil, M., Afsana, F.N., Sadia, K.P., Kamal, K.D., Mrityunjoy, A., Nusrat, J.U., Tasmina, R. and Rashed, N. (2014). Microbiological quality analysis of shrimps collected from local market around Dhaka city. International Food Research Journal, 21(1), 33-38.

Shewry, P.R., Halford, N.G., Belton, P.S. and Tatham A. S. (2002). The structure and properties of gluten: An elastic protein from wheat grain (PDF). Philosophical Transactions of the Royal Society B: Biological Sciences, 357(1418), 133-142. https:// doi.org/10.1098/rstb.2001.1024

Torquato, D., Ferreira, M., Sa, G., Brito, E., Pinto, G. and Azevedo, E. (2004). Evaluation of antimicrobial activity of cashew tree gum. World Journal of Microbiology and Biotechnology, 20, 505-507. https://doi.org/10.1023/

B:WIBI.0000040407.90110.c5

Williams, P.G. (2014) The Benefits of Breakfast Cereal Consumption: A Systematic Review of the Evidence Base1-4. Advances in Nutrition, 5(5), 636S-673S. https://doi.org/10.3945/an.114.006247 